\title{
Sea Ice, Climate, and Icelandic Fisheries in the Eighteenth and Nineteenth Centuries
}

\author{
A.E.J. OGILVIE ${ }^{1}$ and I. JÓNSDÓTTIR ${ }^{2}$
}

(Received 7 April 1999; accepted in revised form 14 September 2000)

\begin{abstract}
The expansion and subsequent decline in catches in many fisheries of the world during the 20th century suggest that the history of fisheries needs our urgent attention. Analysis of environmental effects on fisheries in the past (when overfishing was not an issue) may cast light on current concerns about declining fish stocks. Primary documentary evidence from Iceland was used for preliminary investigations into correlations between sea-ice extent, sea temperatures, ocean currents, and cod fishing, and hence between severe weather and the decline of Icelandic fisheries in the past. The sources suggest that fishing was generally successful in Iceland during the medieval period and well into the 16th century. However, in the 17th through the 19th centuries, the fisheries failed on numerous occasions, sometimes for several years. The causes of these failures were complex. Climate likely played a part, and this was certainly the perception of contemporary writers; however, socioeconomic factors were also involved.
\end{abstract}

Key words: Arctic sea ice, climate/sea interactions, cod fisheries, fisheries history, Iceland

RÉSUMÉ. L'expansion, et le déclin qui suivit, touchant les prises de nombreuses pêcheries dans le monde au cours du XX ${ }^{\mathrm{e}}$ siècle suggèrent que nous devons nous pencher sans tarder sur l'historique de la pêche. Une analyse des répercussions environnementales sur les pêcheries dans le passé (quand la surpêche ne constituait pas un problème) peut jeter de la lumière sur les enjeux actuels concernant l'épuisement des stocks de poissons. Des preuves documentaires primaires provenant d'Islande ont servi aux recherches préliminaires portant sur les corrélations entre l'étendue de la glace marine, les températures de la mer, les courants océaniques et la pêche de la morue - donc entre le mauvais temps et le déclin des pêcheries islandaises dans le passé. Les sources suggèrent que la pêche était généralement fructueuse en Islande durant la période médiévale et les premières décennies du XVI siècle. Toutefois, du XVII ${ }^{\mathrm{e}}$ à la fin du XIX ${ }^{\mathrm{e}}$ siècle, les pêcheries connurent bien des échecs, parfois sur plusieurs années. Les causes en étaient complexes. Si le climat jouait vraisemblablement un rôle-ce que perçurent bien les écrivains de l'époque-, des facteurs socio-économiques entraient aussi en jeu.

Mots clés: glace marine arctique, interactions climat/mer, pêcheries de morue, historique des pêcheries, Islande

Traduit pour la revue Arctic par Nésida Loyer.

\section{INTRODUCTION}

The inhabitants procure...various other species of fish; but particularly the cod-fish, which assemble and keep near those masses of ice that sink deep in the water. (Ólafsson and Pálsson, 1975)

Sea fishing has always been an extremely important part of the Icelandic economy, although it did not become a major industry until the 20th century. The correlation between sea temperature, ocean currents, and fish stocks that has been observed in the 20th century (see e.g., Vilhjálmsson, 1997) suggests that it may be possible to draw conclusions on similar relationships in the past. It is therefore of interest to investigate the extent to which variations in catches of Icelandic fisheries have been driven by climatic or socioeconomic changes, or both.

The context of this research on climate and fisheries is ongoing work on proxy climate records in the North
Atlantic region, which involves comparing marine sediment cores from the Iceland and Greenland shelves, icecore records from the Greenland ice sheet, and documentary historical sea-ice and climate records from Iceland (see e.g., Barlow et al., 1997a; Ogilvie et al., 2000; Jennings et al., in press). The human dimensions of climate impacts have also been considered (Ogilvie, 1984a, 1997, in press; Buckland et al., 1996; Barlow et al., 1997b; Ogilvie and McGovern, 2000). Our present focus is on the analysis of documentary sources, particularly to elucidate contemporary perceptions of the interconnections between climate and fisheries. Preliminary investigations concerned the role of climatic and environmental changes (especially variations in sea ice) and socioeconomic factors in the history of Icelandic fisheries.

Fish, and particularly cod (Gadus morhua), are known to be highly dependent on oceanographic parameters such as temperature (Jónsson, 1969; Malmberg and Blindheim, 1993; Schopka and Marteinsdóttir, 1994; Vilhjálmsson,

\footnotetext{
${ }^{1}$ Institute of Arctic and Alpine Research, University of Colorado, Boulder, Colorado 80309-0450, U.S.A.; ogilvie@ spot.colorado.edu

${ }^{2}$ Department of Geosciences, University of Iceland, IS-101 Reykjavik, Iceland

(C) The Arctic Institute of North America
} 
1997; Gunnarsson et al., 1998). Thus records of variations in the Icelandic fisheries may yield a further climate proxy for the North Atlantic region and increase our understanding of the climate/ocean system.

The fish caught by Icelanders in the past included haddock, halibut, lumpfish, and sharks. Herring was also caught, but only on a very small scale before the last two decades of the 19th century. The most important catch, both for home consumption and for export, was cod. This fish therefore features in the discussion.

\section{SOURCES AND METHODS}

A wide variety of documentary sources relating to the climatic as well as the general history of Iceland have been collected and analyzed (Ogilvie, 1982, 1991, 1992, 1996, 1997; Jónsdóttir, 1995; Ogilvie and Jónsdóttir, 1996; Jónsdóttir and Ogilvie, 1997). These include official governmental records, annals, early newspapers, geographical descriptions, weather diaries, and early sea-ice charts. Certain of these records also contain information on Icelandic fisheries from medieval times to the late 19th century. In addition, we have several detailed contemporary treatises on fish and fisheries written by both Icelanders and foreign observers: an example is the treatise by Jón Ólafsson, Ichtyographia Islandica (1737). In the middle of the 18th century, Eggert Ólafsson and Bjarni Pálsson travelled through Iceland on behalf of the Danish Scientific Society to investigate many aspects of life in Iceland. Their resulting book contains some particularly interesting comments on fisheries (Ólafsson, 1772; Ólafsson and Pálsson, 1975). Other accounts are found in several general descriptions of Iceland (e.g., Horrebow, 1758; Olavius, 1780; Mohr, 1786; Pálsson, 1945; Faber, 1829; Gröndal, 1874).

The history of fisheries in Iceland has already been extensively researched, in particular by Kristjánsson (1971, 1980-86) and Jónsson (1988, 1994a, b). Our contribution is to analyze information on the Icelandic cod fisheries gleaned from the documentary historical sources listed above in the context of changes in climate, specifically sea-ice and ocean changes. Particular emphasis is given to unpublished government reports in the form of letters written from all districts of Iceland by the sýslumenn or district sheriffs (These Bréf til Stiftamtmanns, "Letters to the Governor," are located in the National Archives in Reykjavik. They are identified in the text below as B.S. followed by the relevant district: for example, B.S. Múlasýsla means "Letter from the Múla district"). Some of these sources were written in Icelandic, others in Danish, the official government language of the day. (Quotations given below have been translated into English by Ogilvie.) As these reports have rarely been used by other researchers, they add important new information to the pool of knowledge regarding developments in the Icelandic fisheries. The documents themselves are described in more detail in Ogilvie (1992). Another interesting source from the latter part of the 19th century, quoted extensively here, is a two-part report on the trade and fisheries of Iceland made by Consul Crowe for the British government (Crowe, 1867, 1872). This source does not appear to have been used by other researchers.

All the documentary sources used in this assessment were analyzed carefully to ensure their reliability (see, e.g., Bell and Ogilvie, 1978). The data were then evaluated and quantified. First, we performed a coarse "content analysis" (see, e.g., Moodie and Catchpole, 1976) of the data and categorized both the climate information and fisheries data. Table 1 summarizes fishing catches during the period 1680-1780, using data from the government reports. For this analysis, Iceland was divided into four regions: north, south, west, and east. Blank spaces indicate that no data were found for that particular year or region. There are fewer data for the east than for other regions, probably because this part of Iceland was more sparsely populated than the others and therefore has fewer historical sources. The available information was grouped into categories of "good," "average," or "poor" catches, quantified as 1, 0, and -1, respectively (as in Ogilvie, 1997). A decadal fishing index for the south of Iceland was then calculated by adding the annual values. Although cold conditions and poor fishing coincide for some decades (for example, the 1690s and the 1750s), in as many or more decades the relationship is in the opposite direction. The overall correlation between fishing success and winter/ spring temperature indices for south Iceland is poor. This fact does not, of course, negate the link between fishing and sea temperature, but serves primarily to illustrate the complexity of the issue.

Figure 1 shows a sea-ice index for the period 16001850. In constructing this index, the coastal areas of Iceland were divided into four regions: north, northwest, east and south. Sea ice drifting to the coasts of Iceland occurs most commonly off the northwestern, northern and eastern coasts. It occurs only very rarely off the south coasts. Also, because of the prevailing ocean currents, sea ice virtually never reaches the southwest coast. This index was derived by evaluating data from all the regions of Iceland that reported the presence of ice in any given season in a certain year. Thus it takes into account both the geographical extent and the duration of the ice. The data were then smoothed using a 15-year, low-pass filter to highlight the lower frequency variations. (For further details on this ice index, see, e.g. Ogilvie, 1992, 1996; Ogilvie and Jónsson, in press.)

\section{THE MARINE ENVIRONMENT AROUND ICELAND}

The waters around Iceland are dominated by two major, distinct, and contrasting ocean currents (see Fig. 2). The Irminger Current brings warm, saline Atlantic Water along western Iceland. Opposing this, across Denmark Strait (to 


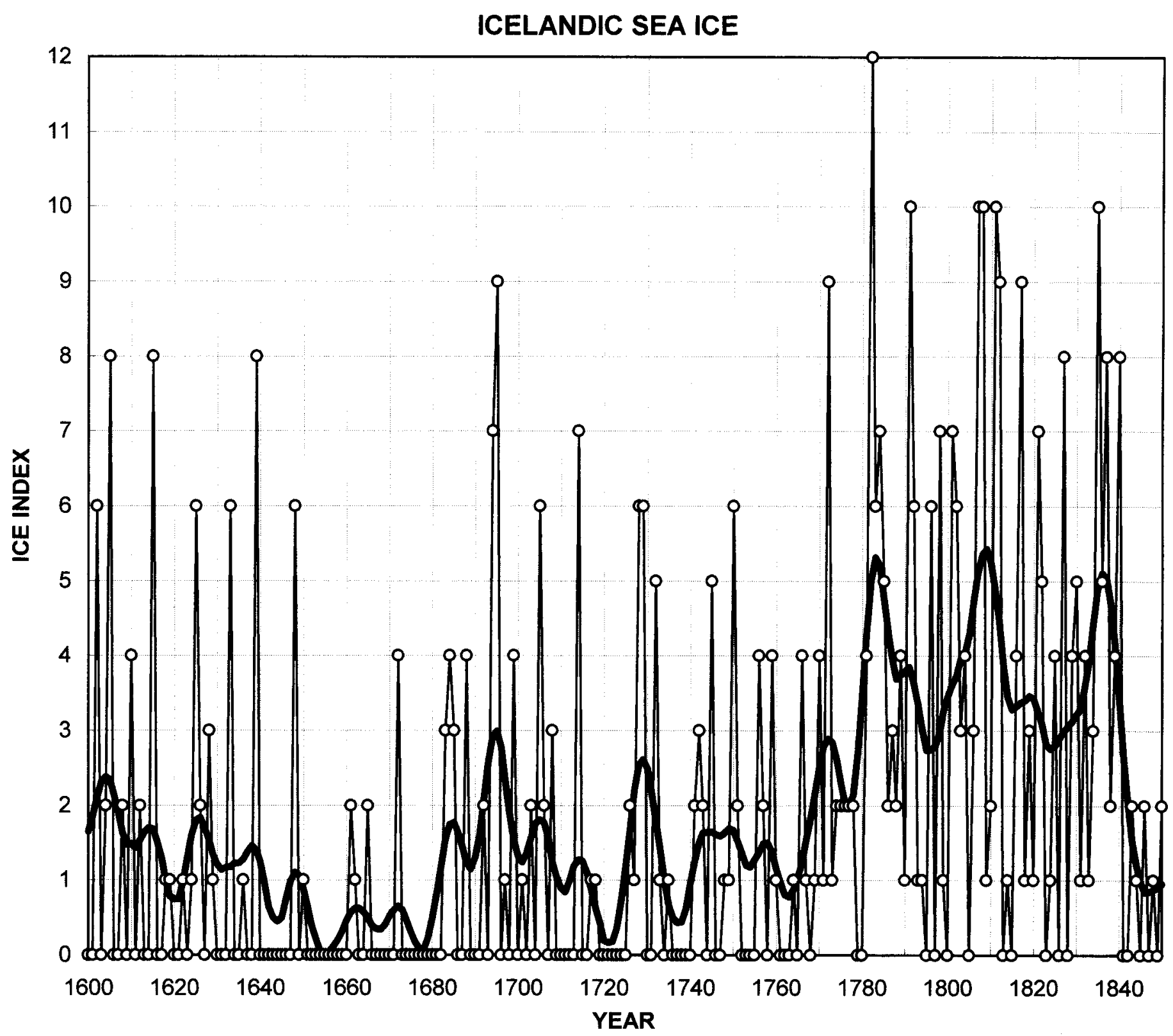

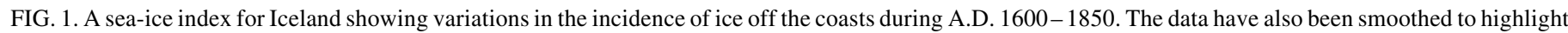
the lower frequency variations using a 15-year low pass filter. The documentary data used to construct this index are described in Ogilvie (1992).

the northwest of Iceland), cold, relatively fresh, polar water from the Arctic Ocean is carried southward in the East Greenland Current. A sharp oceanographic front marks the boundary between the two water masses (Stefánsson, 1969; Malmberg, 1985). For many decades, Icelandic researchers have maintained hydrographic stations, which provide a detailed record of changes in water temperature and salinity (Malmberg and Magnússon, 1982). The record shows a significant correlation between the air temperatures over land and the sea surface temperatures (SSTs) off Iceland (Eythórsson and Sigtryggsson, 1971). Therefore the proxy climate records from offshore and on land can be expected to show similar fluctuations.

The fertility in the waters around Iceland arises from winter convection, bringing nutrients to the near-surface waters, followed by stratification of the ocean column and blooming of zooplankton in spring. Figure 2 also shows the spawning grounds for cod, located to the southwest and south of Iceland, as well as the drift of juvenile cod and the migration of sexually mature cod.

The seasonal boundary of the Arctic drift ice, carried southward by the East Greenland current, also lies close to Iceland. Figure 3 shows the position of the ice edge in relation to the coast of Iceland in both a "normal" severe ice year and a "normal" mild ice year (Eythórsson and Sigtryggsson, 1971). The ice most commonly reaches Iceland in the late winter or early summer and most usually affects the northern and northwestern coasts. The drift ice reaches Iceland via a complex mix of oceanic and atmospheric circulation and local winds and currents. Icelandic 


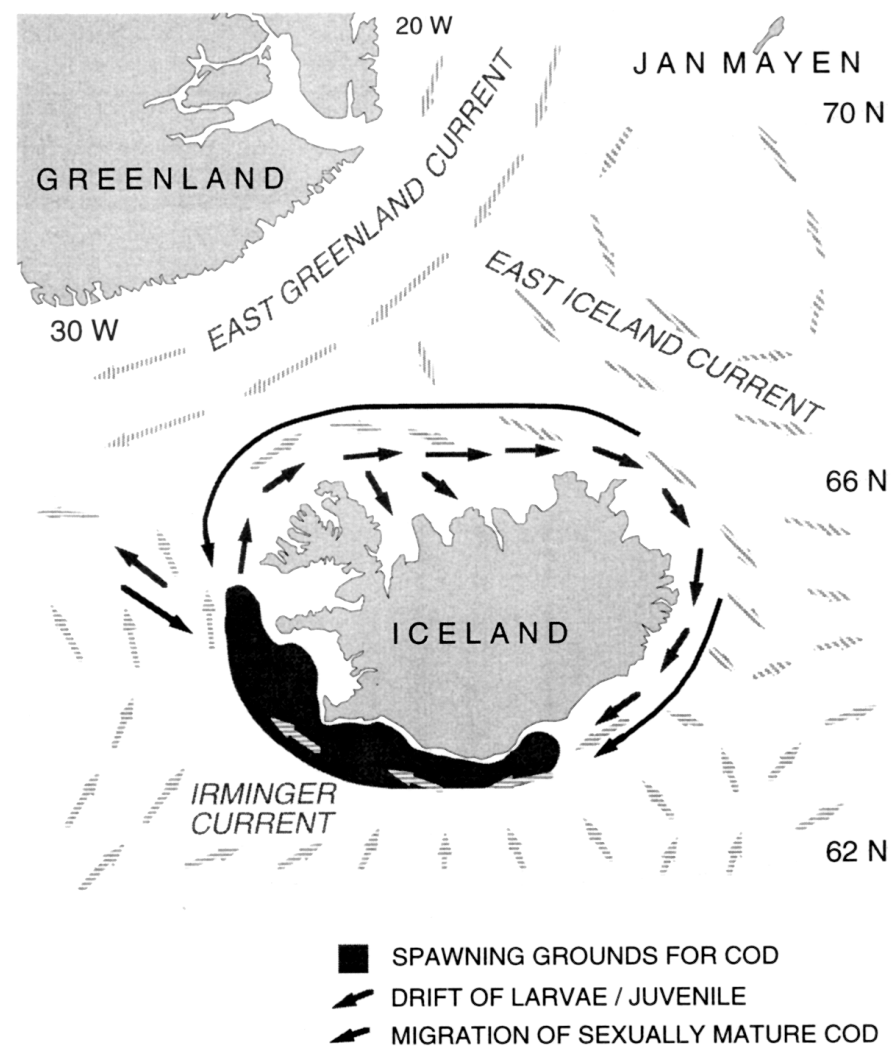

FIG. 2. Ocean currents in Icelandic waters. Also shown are typical spawning areas for cod as well as drift of larvae (short arrows closer to land) and migration of sexually mature cod (long arrow).

ice extremes are associated with interannual variability either in the high-pressure region over Greenland or in deep storms passing farther east over the East Greenland Sea. Both of these circulation features further the advection of ice towards Iceland from its usual location in the East Greenland Sea along the Greenland coast.

\section{THE PAST CLIMATE AND SEA-ICE RECORD FROM ICELAND}

A brief outline of Iceland's climate and sea-ice history is appropriate here. The data used in the following section derive from Ogilvie $(1991,1992)$. For more information, see also Ogilvie (1984b, 1996), Ogilvie and Jónsdóttir (1996), and Jónsdóttir and Ogilvie (1997).

Iceland was first settled in the late ninth century. Since there are no contemporary documents for the first few centuries of settlement, evidence for a relatively mild climate at that time (comparable to the warmest parts of the 20 th century) relies largely on circumstantial evidence and other data sets (Ogilvie et al., 2000). The climate of the succeeding centuries shows considerable variability. Relatively cold periods are suggested during ca. 1180 to 1210 , and again during the 1280 s and 1290s. The 14th century was markedly variable. There is some evidence for a mild climate between 1430 and 1560; however, for much of this

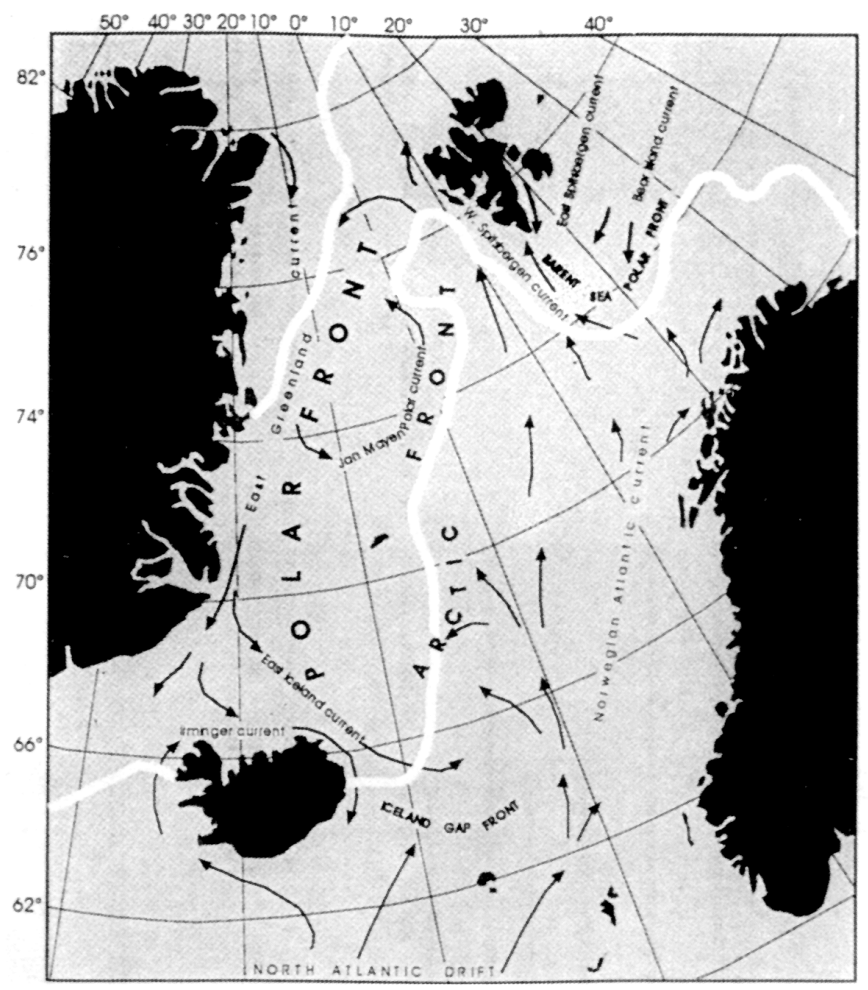

FIG. 3. The position of the sea ice edge in relation to the coast of Iceland in both a "normal" severe ice year (the more southerly white line) and a "normal" mild ice year (the more northerly white line located close to the coast of Greenland). (Modified after Hurdle, 1986).

period documentary sources are lacking. For the latter part of the 16th century, sources suggest a comparatively harsh climate. A cooling trend may be seen around the beginning and end of the 17th century. However, these periods are separated by a mild period from ca. 1640 to 1670 . The early decades of the 18th century were mild in contrast to the very cold 1690s, 1730s, 1740s, and 1750s. The 1760s and $1770 \mathrm{~s}$ show a return to a milder regime, but the $1780 \mathrm{~s}$ are likely to have been the coldest decade of the century, with the harsh conditions compounded by volcanic activity. The $1810 \mathrm{~s}, 1830 \mathrm{~s}$, and 1880 s were also comparatively cold. Overall, the 20th century has had milder temperatures than the preceding three centuries.

The sea-ice data for the period before ca. A.D. 1600 are sparse and do not warrant a statistical analysis; but for the subsequent period, sufficient data are available to construct indices. Figure 1 shows the variations in sea-ice incidence off the coasts of Iceland from A.D. 1600 to 1850. During the early and late decades of the 17th century, much sea ice was present, but from ca. 1640 to ca. 1680, there appears to have been little sea ice off Iceland. During the period 1600-1850, the decades with most ice present were the 1780s, the 1810s, and the 1830s. From 1840 to 1855 , there was virtually no ice off the Icelandic coasts. The presence of sea ice off the coasts of Iceland during some or all of a winter, spring, summer, or autumn season during 1680-1780 is also shown in Table 1. 
Ice incidence after 1850 (not shown in Fig. 1) is briefly summarized here. Frequent ice reappeared around 1855-60; however, the incidence does not seem to have been as heavy as in the earlier part of the century. Further clusters of sea-ice years occurred from ca. 1864 to 1872 . The 1880 s contained several very severe sea-ice years, and some sea-ice years also occurred in the $1890 \mathrm{~s}$, but far less often than in the 1880s. From 1900 onwards, sea-ice incidence fell off dramatically. Clearly, both the sea ice that reaches Iceland's coasts and the temperature on land are highly variable. Further information on sea-ice reconstructions for the period after 1850 may be found in Jónsdóttir (1995) and Ogilvie and Jónsson (in press).

\section{FISHING IN THE ICELANDIC ECONOMY}

Although fishing did not become a major industry in Iceland until the late 19th century and was rarely carried out as an occupation totally separated from farming, it has always been an extremely important part of the Icelandic economy. From early settlement times in the late 9th century, fish formed a major part of the Icelanders' diet, and from the 14th century onwards, fish was the most important export item. From 1602 to 1854, the Danes held a trading monopoly in Iceland and controlled the stockfish (dried cod) trade. After that time, Denmark remained Iceland's main trading partner for many decades. From Denmark, much of the best-quality fish was exported further to Bilbao and Barcelona, "where the Iceland dried cod is much esteemed...The inferior qualities are shipped to England and Denmark" (Crowe, 1867:37).

Iceland's fishing grounds are shown in Figure 4. Before the 20th century, the most important fishing grounds were in the south, particularly off the Vestmannaeyjar (Westman Islands) and in the west, off Snæfellsnes and the Reykjanes peninsula, and in the Faxaflói area. In 1867, Consul Crowe, reporting to England on the trade and fisheries of Iceland (1867:29), noted:

It appears that the large cod remain during the winter near the island, and in February and March approach the south coast to spawn; the fishermen, in Faxe Bay [Faxaflói, in the west], affirm that the direction of the fish is from the south and west.

Crowe (1867:29) also commented:

A glance at the map of Iceland seems to indicate that the long, flat coast stretching from Vestmanns Islands [Vestmannaeyjar] to Vesterhorn, is specially adapted for a spawning ground, and at
TABLE 1. A summary of contemporary perceptions of fishing catches in Iceland, A.D. 1680 to 1780 . The presence of sea ice during winter (W), spring (SP), summer (SM), and autumn (A) is also indicated.

\begin{tabular}{|c|c|c|c|c|c|}
\hline \multirow[t]{2}{*}{ Year } & \multirow[t]{2}{*}{ Sea Ice } & \multicolumn{4}{|c|}{ Fisheries } \\
\hline & & North & South & West & East \\
\hline 1680 & & & Good & & \\
\hline 1681 & & & Small catch & & \\
\hline 1682 & & & & Very good & \\
\hline 1683 & $\mathrm{SP}, \mathrm{SM}$ & Much herring & Poor & Variable & \\
\hline 1684 & $\mathrm{~W}, \mathrm{SP}$ & Good & Very good & Very good & \\
\hline 1685 & $\mathrm{~W}, \mathrm{SP}, \mathrm{SM}$ & & Below average & & \\
\hline 1686 & & & Average & Good & \\
\hline 1687 & & & Poor & Adequate & \\
\hline 1688 & $\mathrm{SP}, \mathrm{SM}$ & & & Little fish & \\
\hline 1689 & & Not much fish & & & \\
\hline 1690 & & Reasonable & Poor & Variable & Poor \\
\hline 1691 & & & Poor & Reasonable & Poor \\
\hline 1692 & $\mathrm{~W}, \mathrm{SP}$ & Good & Poor & Average/Poor & Poor \\
\hline 1693 & & Quite good & Poor & Fair & Poor \\
\hline 1694 & $\mathrm{SP}, \mathrm{SM}$ & Good after ice & Variable/Poor & Quite good & Poor \\
\hline 1695 & SP, SM & Lack & Variable & Average & Poor \\
\hline 1696 & & Poor & Good & Poor & \\
\hline 1697 & W & Poor & & Poor & \\
\hline 1698 & & & Average & Reasonable & \\
\hline 1699 & SP & Poor & Mainly poor & Very poor & \\
\hline 1700 & & Very poor & & Very poor & \\
\hline 1701 & $\mathrm{SM}, \mathrm{A}$ & Lack & Lack & Lack & Better in east \\
\hline 1702 & & Lack & Variable & Small catches & \\
\hline 1703 & SP & Mainly poor & Variable & & Good \\
\hline 1704 & & Good & Quite good & Quite good & Good \\
\hline 1705 & SP, SM & Variable & Lack & Reasonable & Good \\
\hline 1706 & SP & Variable & Variable & Good & Quite good \\
\hline 1707 & & & Good & Variable & Good \\
\hline 1708 & $\mathrm{~W}, \mathrm{SP}, \mathrm{SM}$ & Quite good & Not very good & Small catches & \\
\hline 1709 & & Reasonable & & Good & Not very good \\
\hline 1710 & & Reasonable & Reasonable & Reasonable & \\
\hline 1711 & & Good & & Variable & \\
\hline 1712 & & Good & & Average/Good & \\
\hline 1713 & & Very good & Good & Good & \\
\hline 1714 & $\mathrm{SP}, \mathrm{SM}$ & & Catches small & Poor & \\
\hline 1715 & & Not very good & Average/Poor & Not very good & \\
\hline 1716 & & Good & Poor & Good & Good \\
\hline 1717 & $\mathrm{~A}$ & Poor & Poor & Poor & Good \\
\hline 1718 & SP & Poor & & Poor & \\
\hline 1719 & & & Poor & Reasonable & Poor \\
\hline 1720 & & Good & Poor & Average & \\
\hline 1721 & & Poor & Poor & & Poor \\
\hline 1722 & & Variable & Quite good & Average & Good/Average \\
\hline 1723 & & Good & & & \\
\hline 1724 & & Good & Poor & Reasonable & Poor \\
\hline 1725 & & Good & Good & Good & \\
\hline 1726 & SP & Good & & Reasonable & \\
\hline 1727 & $\mathrm{~W}$ & Good & Good & Quite good & \\
\hline 1728 & SP, SM & Variable & & Fairly good & Good \\
\hline 1729 & $\mathrm{~W}, \mathrm{SP}, \mathrm{SM}$ & Late but good & Good & Average & Very poor \\
\hline 1730 & & Lack & Good & Quite good & Variable \\
\hline 1731 & & Failed & Quite good & Variable & Poor \\
\hline 1732 & $\mathrm{SP}, \mathrm{SM}$ & Poor & Very poor & Great lack & Poor \\
\hline 1733 & $\mathrm{SM}$ & Quite good & Average/Poor & Variable/Poor & Very poor \\
\hline 1734 & & Poor & Failed & Poor & Variable \\
\hline 1735 & SP & Very poor & Below average & Great lack & \\
\hline 1736 & & Quite good & Average & Average/Good & Poor \\
\hline 1737 & & Poor & Poor & & None winter \\
\hline 1738 & & Very poor & Average & Variable & Very poor \\
\hline 1739 & & Variable & Very poor & Mainly poor & \\
\hline 1740 & & Reasonable & & Good & Very poor \\
\hline 1741 & SP & & Average & Variable & Very poor \\
\hline 1742 & $\mathrm{~W}, \mathrm{SP}, \mathrm{SM}$ & Quite good & & Quite good & Poor \\
\hline 1743 & SP, SM & Reasonable & & Average & Very poor \\
\hline 1744 & & Rather poor & Very poor & Variable & \\
\hline 1745 & $\mathrm{~W}, \mathrm{SP}, \mathrm{SM}$ & Lack & Good before ice & Mainly poor & \\
\hline 1746 & & Average/Poor & Average & Very poor & \\
\hline
\end{tabular}


TABLE 1. continued: A summary of contemporary perceptions of fishing catches in Iceland, A.D. 1680 to 1780 . The presence of sea ice during winter (W), spring (SP), summer (SM), and autumn (A) is also indicated.

\begin{tabular}{|c|c|c|c|c|c|}
\hline \multirow[t]{2}{*}{ Year } & \multirow[t]{2}{*}{ Sea Ice } & \multicolumn{4}{|c|}{ Fisheries } \\
\hline & & North & South & West & East \\
\hline 1747 & & Great lack & Small catches & Great lack & \\
\hline 1748 & SP & Poor & Average/Good & Average/Poor & \\
\hline 1749 & $\mathrm{~W}$ & Variable & Average/Poor & Variable & \\
\hline 1750 & $\mathrm{~W}, \mathrm{SP}, \mathrm{SM}, \mathrm{A}$ & Poor & Quite good & Variable & Good \\
\hline 1751 & $\mathrm{~W}, \mathrm{SP}$ & Very poor & Mainly poor & Very poor & Very poor \\
\hline 1752 & & Very poor & Very poor & Mainly poor & \\
\hline 1753 & & Mainly poor & Very poor & Average & \\
\hline 1754 & & Variable & Terrible & Very poor & \\
\hline 1755 & & Very little & Average/Poor & Poor & \\
\hline 1756 & $\mathrm{SP}, \mathrm{SM}$ & No fish & Very poor & Variable & \\
\hline 1757 & $\mathrm{SP}, \mathrm{SM}$ & Poor & Variable & Mainly poor & Quite good \\
\hline 1758 & & Mainly poor & Average & Poor & \\
\hline 1759 & $\mathrm{SP}, \mathrm{SM}$ & Poor & & Reasonable & \\
\hline 1760 & SP & Reasonable & Variable & Average & \\
\hline 1761 & & Very good & Poor & Poor & \\
\hline 1762 & & Good & Rain spoiled & Variable & \\
\hline 1763 & & Mainly good & Very good & Variable & \\
\hline 1764 & SP & Spring good & & Variable & \\
\hline 1765 & & Spring good & Very good & Average & \\
\hline 1766 & W, SP, SM & Variable & Variable & & \\
\hline 1767 & SP & Variable & Not very good & Good & \\
\hline 1768 & & Good & Variable & Good & \\
\hline 1769 & W & Reasonable & Very poor & & \\
\hline 1770 & $\mathrm{SP}, \mathrm{SM}$ & Good & Good & Good & \\
\hline 1771 & SP & Reasonable & Good & & \\
\hline 1772 & W, SP, SM & Good & & Not very good & \\
\hline 1773 & $\mathrm{SP}$ & Reasonable & & Variable & \\
\hline 1774 & $\mathrm{~W}, \mathrm{SP}$ & Good & Mainly poor & Mainly good & Lack \\
\hline 1775 & $\mathrm{SM}$ & Quite good & Mainly poor & Variable & Very poor \\
\hline 1776 & SP & Good & Variable & Variable & Lack \\
\hline 1777 & SP & Quite good & Variable & Quite good & \\
\hline 1778 & SP & Good & Variable & Poor/Average & Very poor \\
\hline 1779 & & Reasonable & Poor & Poor & Very poor \\
\hline 1780 & & Variable & Variable & Variable & Lack \\
\hline
\end{tabular}

the Snefjeldsjökull, the earliest and best fishings commence in February or March, and it is not until towards the end of June, or beginning of July, that the fishings begin further round to the north. Cod is found in great numbers in Faxe Bay as late as May, and in Breiða Bay [Breiðafjörður] in June, and somewhat later along the coast to the northwest.

Throughout the 18th and 19th centuries, the fishing seasons varied from one place to another, determined primarily by when the largest runs of fish occurred in a given place and whether local weather conditions allowed small boats to go to sea. The choice of fishing grounds and the appointed seasons for fishing reflect the movements of the cod during the year (Kristjánsson, 1982), but activities in the seasonal round on land also had to be taken into account.

Around the Vestmannaeyjar (Westman Islands) and Eyrarbakki, the main fishing season was from 28 January to 12 May, after which the fish generally left this area. Around the Reykjanes peninsula, the season lasted from 2 February to 12 May. In Breiðafjord there were two seasons: the autumn season, from 29 September to 23 December, and the spring season, from 10 April to 12 May.
In the western fjords there was just one season, from 10 April to 30 June, but in many places there fish could also be caught in the autumn and winter (Aðils, 1926-27:514-515). Also, according to Crowe (1867:30):

\begin{abstract}
The winter and spring fishings give the large fat cod which is sold at the factories and trading ports, and afterwards prepared for export, while the summer fishings only produce the small cod, cole-fish, haddock, and halibut, which are salted and smoked for home consumption.
\end{abstract}

In the north and east, the best time for fishing was in the spring/summer and autumn. The spring season lasted from April until around the middle of July, and the autumn season, in theory, from around the end of haymaking until November or even Christmas (Kristjánsson, 1982). However, in practice, autumn fishing frequently conflicted with the harvesting of the hay crop, and the fishing was interrupted during the haymaking season every year. This, coupled with the fairly short season, meant that fishing was of less importance in the north and east. A letter written in 1721 by Sheriff Hallgrímur Thorlacius in the Múla district (in the east) illustrates the problem:

The fishing on the coast has been quite good since
July, but because of our grass and hay, which we
have to harvest from the beginning of August, the
ordinary people have not had much benefit from
it. (B.S. Múlasýsla)

\section{FISH AND CLIMATE}

Current research makes the importance of climate in biological responses amongst fish quite clear. However, during the 20th century, the effects of overfishing may have masked environmental impacts on fish (see e.g., McGoodwin, 1990; Hutchings and Myers, 1995; Vilhjálmsson and Jakobsson, 1998; Aagaard et al., 1999; Hamilton and Haedrich, 1999). The link between various aspects of atmospheric and oceanographic conditions and the life cycles and distribution of different species of fish is extremely complex (Woodhead and Woodhead, 1959; Beverton and Lee, 1965; Cushing, 1976; Dunbar, 1976; Stefánsson, 1994; Thór, 1994; Vilhjálmsson, 1997). Nevertheless, certain facts concerning fish and climate are well established. In particular, it appears that sea temperature is the most important ocean climate parameter influencing growth in fish stocks, since it influences all life stages (Sundby, 1998). The cod, for example, is a cold-water fish: temperatures of $4^{\circ}$ 


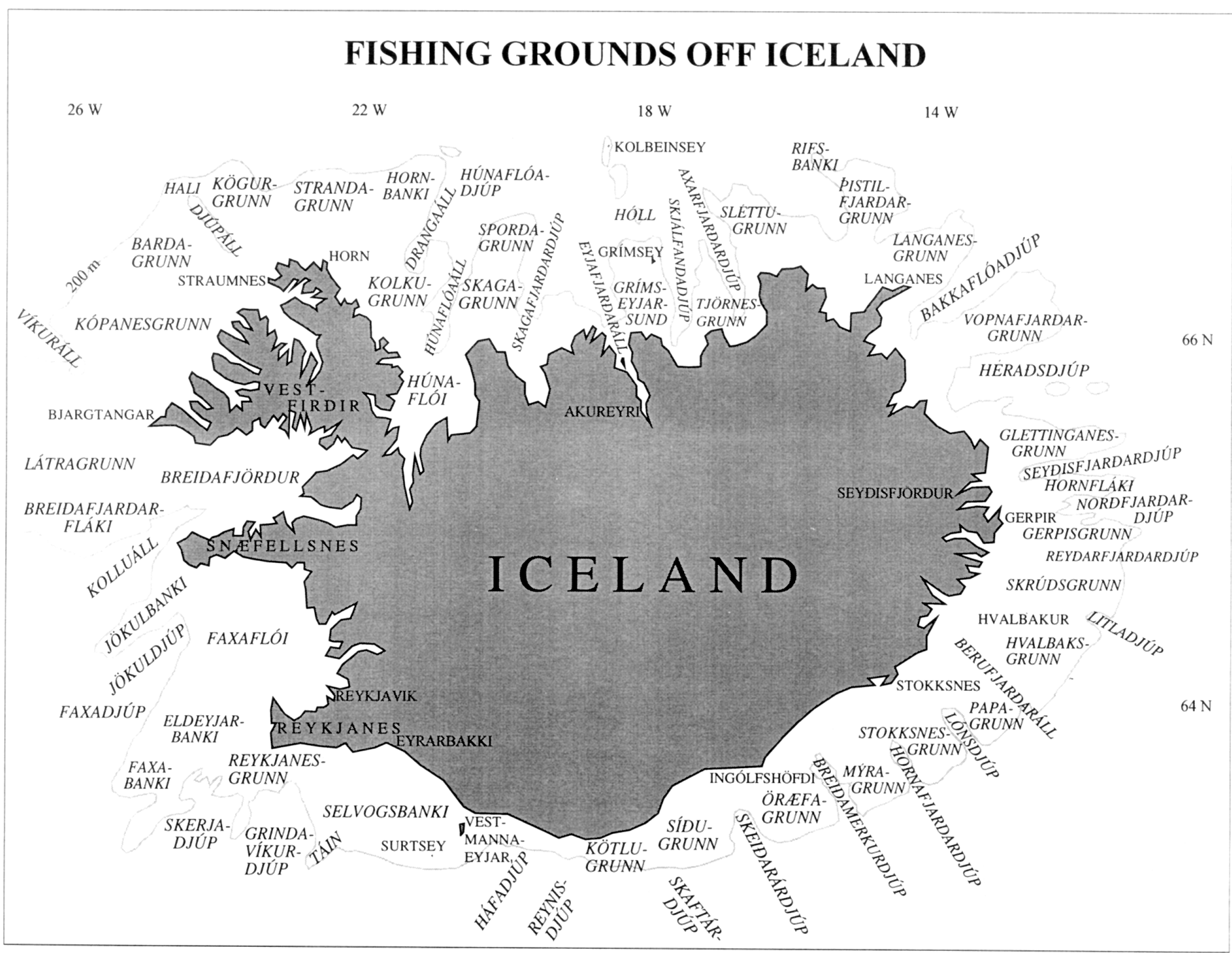

FIG. 4. Fishing grounds off Iceland.

to $7^{\circ} \mathrm{C}$ are optimal for its reproduction and early survival (Jónsson, 1969). This feature of the cod's physiology is reflected in temporal variations in the distribution of the species. Its strict climatic limits make the cod likely to be a useful climate indicator. Other important ocean climate parameters are turbulence and light conditions (Sundby, 1998).

A marked warming occurred in the Iceland and Greenland areas in the 1920s and 1930s (Jones et al., 1999), and many changes in fish distributions were observed during this period. A striking example was the mass spawning of cod off northern and eastern Iceland in addition to the usual spawning off the southern and western coasts (see Fig. 2 for "average" conditions) and the drift of cod larvae west to Greenland (Sæmundsson, 1934). Climatic deterioration in this area of the North Atlantic in the late 1960s, manifested by increasing drift ice, low air temperature, and a marked drop in ocean temperature and salinity, had wide-ranging repercussions on the ecology of the waters (Thórdardóttir, 1977). This climatic cooling also greatly reduced the size of the zooplankton community. The change here was so great that it has been described as a change in marine species composition from boreal to arctic (Jakobsson, 1978; Ástthórsson et al., 1983). During this time, however, an unfortunate combination of improved modern fishing technology and an unusually high fish population led to overfishing.

The dramatic improvement in climatic conditions in Icelandic waters that took place in the first half of the 20th century led to radical changes in the quantity, distribution, and reproduction of the fish fauna (Vilhjálmsson, 1997). These changes also had a very strong socioeconomic impact in Iceland, in that revenue from the fishing industry greatly increased prosperity. Recent research suggests that subsequent changes have been more complex, involving an interplay between environmental and exploitation factors (O’Brien et al., 2000).

\section{CLIMATE IMPACT STUDIES IN ICELAND}

Research into the socioeconomic impacts of climate and climate change in Iceland may be said to have begun in the 18th century, with works such as Finnsson (1796). 
For a discussion of this and other relevant works, see Ogilvie (1982) and Ogilvie and Jónsson (in press). Some modern researchers have also asserted the considerable importance of climatic and environmental effects in the shaping of Icelandic history (see, e.g., Thórarinsson, 1956; Andrésson, 1964; Bergthórsson, 1966; Friðriksson, 1969; Ogilvie, 1982, 1984b, 2000), but others have suggested that climate has had a minimal effect and stressed the importance of socioeconomic factors alone (see, e.g., Gunnarson, 1980, 1983, 1987). The debate on whether environmental or socioeconomic factors are most important is not entered into here. However, although climate determinism arguments are too simplistic, climatic and environmental elements cannot be ignored when considering the history of a marginal area for settlement such as Iceland.

Climate impact on fisheries in the past has also begun to be explored. It has been suggested, for example, that the failure of the Færoese cod fishery during the 17th and 18th centuries was due to a reduction in sea-surface temperatures (Lamb, 1979). This issue has also been discussed by Jónsson (1994b), and Ogilvie (1982, 1997).

Little doubt surrounds the specific effects of sea ice on the Icelandic populace in the past. Three main negative impacts may be mentioned. First, the presence of ice had the effect of lowering temperatures on land (Friðriksson, 1969). This, in turn had a detrimental effect on the allimportant grass crop, which provided fodder for the livestock (Ogilvie, 1984a). Second, with an extensive ice cover around Iceland's coasts, trading vessels carrying vital supplies were unable to land. Third, and of particular relevance here, the sea ice prevented access to fishing grounds. Occasionally, the sea ice also brought benefits with it, in the form of driftwood and marine mammals such as seals and whales. Further research will help resolve the question of whether the presence of a certain amount of sea ice (but not enough to completely block the coasts) brought, for example, certain nutrients in its wake, and therefore had a positive impact on fisheries.

\section{CONTEMPORARY PERCEPTIONS REGARDING FISHERIES' CATCHES}

Historical sources suggest that fishing was generally successful in Iceland from early settlement times to the 16th century, and there are few records of fisheries failing. However, our analyses suggest that in the 17th and 18th centuries, the fisheries failed on numerous occasions, sometimes for several years (see also Aðils, 1926-27; Jónsson, 1969; Kristjánsson, 1971; Ogilvie, 1982, 1997). Table 1 summarizes contemporary perceptions of fishing catches for the period 1680-1780. Jónsson (1994b) has made a similar analysis, using different data. These independent analyses show some disagreement, and a closer comparison of the two data sets is required.

Catches during the 18th century, in particular, appear to have declined. The many years when fishing was described as "poor" or "lacking" in Table 1 illustrate this clearly. For example, in the mid-17th century in the south of Iceland, one man would have been expected to catch, on average, about 500 cod during the winter fishing season; but after the mid-18th century, 300 cod were regarded as the maximum catch (Aðils, 1926-27:515). The number of fish exported also fell in the 18th century. Most contemporary writers seem to have noticed this decline and remarked upon it. Certainly the poor catches are reflected in the reports of Icelandic officials. A typical example is the account for 1722 from the Sheriff of Pingeyjar district in the northeast, who wrote: "The fishing is very poor in the north, and decreases every year" (B.S. Pingeyjarsýslu). Similar reports came from other regions. The account below for 1747 is from Barðastrand district in the northwest:

In the west, the fishing was poor; there were average to small catches of lumpfish, but everywhere the cod catch was the worst that people could remember for many years, both during the autumn fishing last year and this spring. In most places most boats did not catch more than about ten fish, and in many places, less. (B.S. Barðastrandarsýsla)

Clearly, poor fishing was often associated with the presence of sea ice in the minds of many contemporaries. Thus, for example, the Sheriff of Skagafjörður in the north noted in 1729 that fishing "occurred late because of the sea ice..." and again in 1733, "The fish seem not to have come as close to the land as usual. This is believed to be because of the drift ice...” (B. S. Skagafjarðarsýsla).

\section{POSSIBLE EXPLANATIONS FOR VARIATIONS IN FISHERIES' CATCHES}

Data analyzed here show that fishing was generally poor, for example, from about 1680 to 1760 (except during the 1720s). Of the several possible explanations for this, some are socioeconomic. When fish disappeared from some fishing grounds, for whatever reason, people who had lived in these areas and were dependent on fishing had to leave their homes and try to find a living elsewhere. When and if the fish returned, the population able to go out fishing was depleted.

The great smallpox epidemic of 1707-08, which wiped out one-third of Iceland's population, had a significant negative impact on fisheries. Farmers living in the coastal regions had great difficulty finding enough people to man their boats (Aðils, 1926-27:516-517). This fact may be illustrated by the following example:

Instead of the usual fourteen or fifteen boats from Ólafsvík only two could be manned this year because of the lack of labour. Many people who lived by the coast have left and the people who live further inland do not want to risk setting out to fish because of the recent failure of the fishing. (B. S. Húnavatnssýsla, 1732) 
The lack of labour meant that smaller boats had to be built. In the 17 th century, boats with 10 or 12 oars were most usual, but boats for six or fewer men came into use before the middle of the 18th century. This change, apart from anything else, would mean smaller total catches.

Other factors should also be considered. In particular, during the 17th and 18th centuries, the Icelanders had only fairly small, open rowing boats (decked vessels did not come into use until the mid-19th century) and were therefore restricted in the distance they could travel, as well as in the time they could spend at sea. Crowe makes some interesting comments. Although he points out the technological inferiority of the Icelanders' boats and equipment, he also observes that in many places (for example, Vogur in Faxaflói and Bolungarvík in Ísafjörður), the fishing is best done close to shore, where small boats are better than ships, and that small boats are "generally more suitable for casting out and attending to deep-sea lines." He adds:

Owing likewise to the eminently inhospitable character of much of the coast, larger vessels would be exposed to serious dangers for want of harbours of refuge, whereas small flat-bottomed craft can run in everywhere, and with ease and safety be drawn up on land at night. (Crowe, 1872:640)

However, Crowe (1867:30) also attests that the Icelanders did "often put many miles out to sea." The general seaworthiness of the Icelanders' fishing boats may also be relevant when considering fishing catches. Crowe (1872:640-641) thought the sails they used seemed unsuitable: too large, and liable to make the boat capsize in a squall. In addition, the rudders were too loose and "in critical moments, often useless." Crowe also suggests that the Icelanders did not maintain their boats as well as they might:

The Icelander is an excellent mariner, his powers of endurance, courage, and ability to keep the sea in all weathers is above praise, but his recklessness as to the soundness of the craft he trusts his life to is equally remarkable.

The numerous shipwrecks, and consequent loss of life, documented in the sources support Crowe's remarks.

However, it is unlikely that factors such as the state of the boats could, on their own, account for a decline in catches during the 18th century, and additional explanations must be sought. One suggestion is that the Dutch, who persistently fished in Icelandic waters during that century, caused depletion of the stocks (see, e.g. Guðnason, 1957:220). Certainly there are numerous complaints to this effect from contemporary Icelanders, but it seems unlikely that Dutch catches would have made any significant difference to the overall availability of fish. Foreign vessels had frequently fished in Icelandic waters since the 15 th century, but there is no evidence to suggest that the stocks were in any way affected by this exploitation.
Compared with modern catches, pre-20th century catches must have been very small.

Another possible explanation of poor fishing catches in Iceland in the past is a real decline in fishing stocks related to climate, more specifically to sea temperatures and ocean currents. It is possible that during a cold period, as in the 18th century, the range of the cod could have withdrawn southward. During that century, the Arctic sea ice frequently reached the coasts of Iceland. The presence of the ice would certainly have had a negative impact on fishing, both because its effect in lowering temperatures could have been detrimental to the fish stocks and because its presence off the coast prevented people from going out to fish.

\section{CONCLUSIONS}

Modern analyses (see e.g., Vilhjálmsson, 1997) have clearly demonstrated a link between environmental variations in the atmosphere and marine life in the oceans. The preliminary investigations on interactions between climate and fisheries conducted here and elsewhere (e.g., Jónsson, 1994b) indicate that such a link also existed in the past. As yet, however, the evidence is not clearly defined. There is no doubt that catches off the coasts of Iceland in the 17th to 19th centuries varied greatly and did indeed decline to very low levels at certain times. The years between about 1680 and 1760, for example, seem to have been mainly poor for fishing. Socioeconomic factors were partly the cause of this. However, the severe climatic conditions during these years must also have had more direct effects. Cold ocean temperatures would almost certainly have reduced fish stocks. Furthermore, the presence of sea ice could prevent people from going fishing and thus reduce the catches. The position of the ice edge could also change the nutrient status of the water, bringing productivity changes that would affect fish populations. (Ólafsson and Pálsson's statement that the fish stayed near to the sea-ice edge, quoted at the start of this paper, suggests that this could be the case.) Thus, the influences of climate involve a complex interplay between socioeconomic factors and direct climatic effects on fish populations that may act in either positive or negative directions. Further research is required to unravel this tangled skein.

\section{ACKNOWLEDGEMENTS}

Funding from the National Science Foundation, U.S.A. (Grant no. OPP-9726510) is gratefully acknowledged. The authors also wish to thank the reviewers of this paper for their comments.

\section{REFERENCES}

AĐILS, J.J. 1926-27. Den Danske Monopolhandel På Island 1602-1787. Oversat af Friðrik Ásmundsson Brekkan, Udgivet 
af Dansk-islands Samfund med Støtte fra Grosserersocietetet og Dansk-islands Forbundsfond, Copenhagen.

AAGAARD, K., DARBY, D., FALKNER, K, FLATO, G., GREBMEIER, J., MEASURES, C., and WALSH, J. 1999. Marine Science in the Arctic: A Strategy. Fairbanks: Arctic Research Consortium of the United States (ARCUS). 84 p.

ANDRÉSSON, S.F. 1964. Harðindi á Íslandi 1800-1803. Skírnir (Tímarit Hins Íslenska Bókmenntafélags) 138:5-44.

ÁSTTHÓRSSON, Ó.S., HALLGRÍMSSON, I., and JÓNSSON, G. 1983. Variations in zooplankton densities in Icelandic waters in spring during the years 1961-1982. Rit Fiskideildar 7(2): $73-113$.

BARLOW, L.K., ROGERS, J.C., SERREZE, M.C., and BARRY, R.G. 1997a. Aspects of climate variability in the North Atlantic sector: Discussion and relation to the GISP2 isotopic signal. Journal of Geophysical Research 102(C12): 26,333-26,344.

BARLOW, L.K., SADLER, J.P., OGILVIE, A.E.J., BUCKLAND, P.C., AMOROSI, T., INGIMUNDARSON, J.H., SKIDMORE, P., DUGMORE, A.J., and McGOVERN, T.H. $1997 \mathrm{~b}$. Interdisciplinary investigations of the end of the Norse Western Settlement in Greenland. The Holocene 7(4):489-499.

BELL, W.T., and OGILVIE, A.E.J. 1978. Weather compilations as a source of data for the reconstruction of European climate during the medieval period. Climatic Change 1:331-348.

BERGTHÓRSSON, P. 1966. Hitafar og búsæld á Íslandi. Veðrið 11(1):15-20.

BEVERTON, R.J.H., and LEE, A.J. 1965. Hydrographic fluctuations in the North Atlantic Ocean and some biological consequences. In: Johnson, C.G., and Smith, L.P., eds. The biological significance of climatic changes in Britain. London: Academic Press. 79-107.

BUCKLAND, P.C., AMOROSI, T., BARLOW, L.K., DUGMORE, A.J., MAYEWSKI, P.A., McGOVERN, T.H., OGILVIE, A.E.J., SADLER, J.P., and SKIDMORE, P. 1996. Bioarchaeological and climatological evidence for the fate of Norse farmers in medieval Greenland. Antiquity 70(267):88-96.

CROWE, J.R. 1867. Report on the Fisheries, Trade and General Features of Iceland for the years 1865-66. London: Commercial Reports received at the Foreign Office from Her Majesty's Consuls No. 2:29-42.

1872. Report on the Trade and Fisheries of Iceland for the years 1870-71. London: Commercial Reports received at the Foreign Office from Her Majesty's Consuls No. 2:637-651.

CUSHING, D.H. 1976. The impact of climatic change on fish stocks in the North Atlantic. The Geographical Journal 142(2):216-227.

DUNBAR, M.J. 1976. Climatic change and northern development. Arctic 29:184-193.

EYTHÓRSSON, J., and SIGTRYGGSSON, H. 1971. The climate and weather of Iceland. Zoology of Iceland 1(3). Copenhagen and Reykjavík: Ejnar Munksgaard.

FABER, F. 1829. Naturgeschichte der Fische Islands. Frankfurt am Main: Heinrich Ludwig Brönner.

FINSSON, H. 1796. Mannfækkun af Hallærum. Republished 1970. Jón Eythórsson og Jóhannes Nordal sau um útgáfuna. Reykjavík: Almenna Bókfélagið.
FRIĐRIKSSON, S. 1969. The effects of sea ice on flora, fauna, and agriculture. Jökull 19:146-157.

GRÖNDAL. B. 1874. Dýraríki Íslands. Reykjavík.

GUĐNASON, B. 1957. Sýslulýsingar 1744-1749, Sögurit 28. Reykjavík: Sögufélagið.

GUNNARSON, G. 1980. A study of causal relations in climate and history with an emphasis on the Icelandic experience. Lund: Meddelande från ekonomisk-historiska institutionen, Lunds universitet Nr. 17.

1983. Monopoly trade and economic stagnation. Studies in the foreign trade of Iceland 1602-1787. Lund: EkonomiskHistorisk Föreningen.

— 1987. Upp er boðið Ísaland. Einokunarverslunin og íslenskt samfélag 1602-1787. Reykjavik: Örn og Örlygur.

GUNNARSSON, K., JÓNSSON, G., and PÁLSSON, Ó.K. 1998. Sjávarnytjar við Ísland. Reykjavík: Mál og Menning. 282 p.

HAMILTON, L.C., and HAEDRICH, R.L. 1999. Ecological and population changes in fishing communities of the North Atlantic Arc. Polar Research 18(2):383-388.

HORREBOW, N. 1758. The natural history of Iceland... Interspersed with an account of the island, by Mr. Anderson. To which is added, a meteorological table, with remarks. Translated from the Danish original. London: A. Linde.

HURDLE, B.G. 1986. The Nordic seas. New York: SpringerVerlag. 777 p.

HUTCHINGS, J.A., and MYERS, R.A. 1995. The biological collapse of Atlantic cod off Newfoundland and Labrador: An exploration of historical changes in exploitation, harvesting technology and management. In: Arnason, R., and Felt, L., eds. The North Atlantic fisheries: Successes, failures and challenges. An Island Living Series, vol. 3. Charlottetown, Prince Edward Island: The Institute of Island Studies. 37-93.

JAKOBSSON, J. 1978. The north Icelandic herring fishery and environmental conditions 1960-1968. ICES Symposium on the Biological Basis of Pelagic Fish Stock Management. Paper No. $30.101 \mathrm{p}$.

JENNINGS, A.E., HAGEN, S., HARĐARDÓTTIR, J., STEIN, R., OGILVIE, A.E.J., and JÓNSDÓTTIR, I. In press. Oceanographic change and terrestrial human impacts in a post AD 1400 sediment record on the southwest Iceland shelf. Climatic Change.

JONES, P.D., NEW, M., PARKER, D.E., MARTIN, S., and RIGOR, I.G. 1999. Surface air temperature and its changes over the past 150 years. Reviews of Geophysics 37:173-199.

JÓNSDÓTTIR, I. 1995. Sea ice off the coasts of Iceland in the early 20th century. Unpublished M.Phil. thesis. Cambridge: Scott Polar Research Institute, University of Cambridge.

JÓNSDÓTTIR, I., and OGILVIE, A.E.J. 1997. Sea ice off the coasts of Iceland in historical times. In: Lewkowicz, A.G., and Kokel, S.V., eds. 27th International Arctic Workshop, Program and Abstracts, 27 February-2 March 1997, The University of Ottawa, Canada. 124-125.

JÓNSSON, J. 1969. Áhrif sjávarhita á vöxt og viðgang prsksins við Ísland og Grænland. In: Einarsson, M.Á., ed. Hafísinn. Reykjavík: Almenna Bókafélagið. 488-511.

— 1988. Hafrannsóknir við Ísland I. Frá öndverðu til 1937. Reykjavík: Bókaútgáfa Menningarsjóðs. 340 p. 
. 1994a. Útgerð og aflabrögð við Ísland 1300-1900. Hafrannsóknir 48. Hafrannsóknastofnun, Reykjavík. 107 p. 1994b. Fisheries off Iceland, 1600-1900. International Convention for the Exploration of the Seas (ICES), Marine Science Symposium 198:17-30.

KRISTJÁNSSON, L. 1971. Sjóslysaárin miklu. Saga 9:158-170. -. 1980-86. Íslenskir sjávarhættir 1-5. Reykjavik: Bókaútgáfa menningarsjóðs.

LAMB, H.H. 1979. Climatic variation and changes in the wind and ocean circulation: The Little Ice Age in the Northeast Atlantic, Quaternary Research 11 (1):1-20.

MAGNÚSSON, S. Lýsing Gullbringu- og Kjósarsýslu. Landnám Ingólfs. Safn til sögu pess. Ingólfur 1935-40. 1 bindi. Reykjavík: Hinu Íslenzka Bókmentafélagi.

MALMBERG, S.-A. 1985. The water masses between Iceland and Greenland. Journal of the Marine Research Institute 9: $127-140$.

MALMBERG, S.-A., and BLINDHEIM, J. 1993. Climate, cod and capelin in northern waters. ICES 1993/CCC Symposium No. 20. $20 \mathrm{p}$.

MALMBERG S.-A., and MAGNÚSSON, G. 1982. Sea surface temperature and salinity in South Icelandic waters in the period 1868-1965. Rit Fiskideildar 3:1-31.

McGOODWIN, J.R. 1990. Crisis in the world's fisheries: People, problems, and policies. Stanford: Stanford University Press.

MOHR, N. 1786. Fors $\varnothing \mathrm{g}$ til en Islandsk Naturhistorie med adskillige oekonomiske samt andre Anmærkninger. Copenhagen: Trykt hos Christian Friderick Holm.

MOODIE, D.W., and CATCHPOLE, A.J.W. 1976. Valid climatological data from historical sources by content analysis. Science 193:51-53.

NATIONAL ARCHIVES, ICELAND. (Pjóðskjalasafn Íslands, Laugavegi 162. IS 105 Reykjavík Iceland)

Bréf úr Barðastrandarsýslu til Stiftamtmanns 1709-1785

Bréf úr Húnavatnssýslu til Stiftamtmanns 1711-1735

Bréf úr Múlasýsla til Stiftamtmanns 1708-1768

Bréf úr Skagafjarðarsýsla til Stiftamtmanns 1708-1740, $1741-1790$

Bréf úr Pingeyjarsýsla til Stiftamtmanns 1707-1751

O'BRIEN, C.M., FOX, C.J., PLANQUE, B., and JOHN, J. 2000. Fisheries: Climate variability and North Sea cod. Nature 404:142. OGILVIE, A.E.J. 1982. Climate and society in Iceland from the Medieval Period to the late eighteenth century. Unpubl. Ph.D. Dissertation, University of East Anglia, Norwich, U.K.

- 1984a. The impact of climate on grass growth and hay yield in Iceland: A.D. 1601 to 1780. In: Mörner, N-A., and Karlén, W., eds. Climate changes on a yearly to millennial basis. Dordrecht: Reidel. 343-352.

1984b. The past climate and sea-ice record from Iceland, part 1: Data to A.D. 1780. Climatic Change 6:131-152. 1991. Climatic changes in Iceland A.D. c. 1500 to 1598. In: Bigelow, G.F., presentor. The Norse of the North Atlantic. Acta Archaeologica Vol. 61-1990. Copenhagen: Munksgaard. 233-251.

1992. Documentary evidence for changes in the climate of Iceland, A.D. 1500-1800. In: Bradley, R.S., and Jones, P.D., eds. Climate since A.D. 1500. London: Routledge. 92-117.
. 1996. Sea-ice conditions off the coasts of Iceland A.D. 1601-1850 with special reference to part of the Maunder minimum period (1675-1715). In: Pedersen, E.S., ed. AmSVaria 25. Stavanger: Archaelogical Museum. 9-12.

1997. Fisheries, climate and sea ice in Iceland: An historical perspective. In: Vickers, D., ed. Marine resources and human societies in the North Atlantic since 1500. St. Johns: Institute of Social and Economic Research, Memorial University of Newfoundland. 69-87.

- In press. Climate and farming in northern Iceland, ca. 1700-1850. In: Sigurðsson, I., and Skaptason, J., eds. Aspects of the history of the Arctic and Sub-Arctic region. Reykjavík: The University Press.

OGILVIE, A.E.J., and JÓNSDÓTTIR, I. 1996. Sea-ice incidence off the coasts of Iceland: Evidence from historical data and early sea-ice maps. In: 26th International Arctic Workshop, Arctic and Alpine Environments, Past and Present. Program with Abstracts of a conference held 14-16 March 1996 at INSTAAR, Boulder, Colorado. 109-110.

OGILVIE, A.E.J., and JÓNSSON, T. In press. "Little Ice Age" research: A perspective from Iceland. Climatic Change.

OGILVIE, A.E.J., and McGOVERN, T.H. 2000. Sagas and science: Climate and human impacts in the North Atlantic. In: Fitzhugh, W.W., and Ward, E.I. eds. Vikings: The North Atlantic saga. Washington, D.C.: Smithsonian Institution Press. 385-393.

OGILVIE, A.E.J., BARLOW, L.K., and JENNINGS, A.E. 2000. North Atlantic climate c. A.D. 1000: Millennial reflections on the Viking discoveries of Iceland, Greenland and North America. Weather 55(2):34-45.

ÓLAFSSON, J. 1737. Ichtyographia Islandica. Hdrs. Jóns Sigurðssonar No. 247, 8to. Unpublished manuscript held in the National Library, (Landsbókasafn Íslands-Háskólabókasafn) Arngrímsgötu 3. IS 107 Reykjavík, Iceland.

- 1772. Vice-Lavmand Eggert Olafsens og Land-Physici Biarne Povelsens Reise igiennem Island, foranstaltet af Videnskabernes Saelskab i København, og beskreven af forbemelte Eggert Olafsen, med dertil hørende 51 KobberStøkker og et nyt forfaerdiget Kart over Island. 2 vols. Søroe, Denmark.

ÓLAFSSON, E., and PÁLSSON, B. 1975. Travels in Iceland 1752-1757. Revised English edition published in 1975. Reykjavík: Bókaútgáfan Örn og Örlygur hf. 186 p.

OLAVIUS, Ó. 1780. Oeconomisk Reise igiennem de nordvestlige, nordlige, og nordöstlige Kanter af Island, ved Olaus Olavius I-II. Copenhagen: Gyldendal.

PÁLSSON, S. 1945. Ferðabók, dagbækur og ritgerðir 1791-1797. Reykjavík: Snælands útgáfan.

SCHOPKA, S.A., and MARTEINSDÓTTIR, G. 1994. Ástand og afrakstur helstu nytjabotnstofna á Íslandsmiðum. In: Stefánsson, U. ed. Íslendingar, hafið og auðlindir pess. Reykjavík: Vísindafélag Íslendinga. 107-127.

STEFÁNSSON, U. 1969. Near surface temperature in the Icelandic coastal waters. Jökull 19:29.

1994. Hafstraumar, ástand sjávar og frjósemi íslenskra hafsvæða. In: Stefánsson, U., ed. Íslendingar, hafið og auðlindir pess. Reykjavík: Vísindafélag Íslendinga. 39-63. 
SÆMUNDSSON, B. 1934. Probable influence of changes in temperature in the marine fauna of Iceland. Rapports et ProcèsVerbaux des Réunions Conseil International pour l'Exploration de la Mer 86:16.

SUNDBY, S. 1998. Growth in plankton and fish stocks in relation to interannual to decadal-scale climate fluctuations-examples from the Nordic seas. North Atlantic Climate Impacts. An international workshop on environmental and climatic variations and their impact in the North Atlantic region held 23-26 September 1998. Reykjavik: Icelandic Research Council. 27.

THÓR, J.P. 1994. Sjórinn sem undirstaða búsetu á Íslandi. In: Stefánsson, U., ed. Íslendingar, hafið og auðlindir pess. Reykjavík: Vísindafélag Íslendinga. 11-17.

THÓRARINSSON, S. 1956. The thousand years struggle against ice and fire. Reykjavík: Museum of Natural History, Department of Geology and Geography, Miscellaneous Papers 14.
THÓRDARDÓTTIR, TH. 1977. Primary production in North Icelandic waters in relation to recent climatic changes. In: Dunbar, M.J., ed. Polar oceans. Calgary: The Arctic Institute of North America. 655-665.

WOODHEAD, P. M. J., and WOODHEAD, A.D. 1959. The effects of low temperatures on the physiology and distribution of cod, Gadus morhua L., in the Barents Sea. London: Proceedings of the Zoological Society 133:181-199.

VILHJÁLMSSON, H. 1997. Climatic variations and some examples of their effects on the marine ecology of Icelandic and Greenland water, in particular during the present century. Rit Fiskideildar 15(1):9-29.

VILHJÁLMSSON, H., and JAKOBSSON, J. Relations between environmental fluctuations and fisheries management. In: North Atlantic Climate Impacts, An international workshop on environmental and climatic variations and their impact in the North Atlantic region held 23-26 September 1998. Reykjavik: Icelandic Research Council. 28-29. 